\title{
Pertanggungjawaban Perdata Pemerintah Daerah Dompu dalam Pengadaan Tanah Pemukiman Warga Desa Jala
}

\author{
Dini Panca Wardani, Rachmad Safa'at, Tunggul Anshari SN. \\ Universitas Brawijaya \\ dhienyharto@yahoo.com
}

\begin{abstract}
Land procurement for public interest is the realization of the mandate of article 6, 27, 34, 40 UUPA, and as a mandate from Law Number 39 of 1999 on Human Rights which mandates that as a consequence of land resources is one part of human rights. The basis problem concerns in the implementation of land rights procurement are: "With respect to land rights whose status of land rights will be revoked or exempted, it can be said that the most essential element in the procurement of land rights is compensation granted in lieu of rights that have been revoked or exempted. In the practice of land procurement conducted by the government is often not in accordance with the ideals of the law. Where it often happens in the implementation of land acquisition for the public interest does not pay attention to the benefit of individual rights, individual rights are often in a position disadvantaged by the government.
\end{abstract}

Keywords: land procurement, compensation, liability.

\begin{abstract}
Abstrak
Pengadaan tanah untuk kepentingan umum merupakan realisasi dari amanat pasal 6, 27, 34, 40 UUPA dan sebagai amanat dari Undang-undang Nomor 39 Tahun 1999 tentang Hak Asasi Manusia yang mengamanatkan bahwa sebagai konsekuensi sumberdaya tanah merupakan salah satu bagian dari Hak Asasi Manusia (HAM).Masalah pokok yang menjadi sorotan atau perhatian dalam pelaksanaan pengadaan hak atas tanah adalah hal - hal menyangkut hak-hak atas tanah yang status dari hak atas tanah itu akan dicabut atau dibebaskan, sehingga dapat dikatakan bahwa unsur yang paling pokok dalam pengadaan hak atas tanah adalah ganti rugi yang diberikan sebagai pengganti atas hak yang telah dicabut atau dibebaskan tersebut. Dalam praktek pengadaan tanah yang dilakukan oleh pemerintah seringkali tidak sesuai dengan apa dicita-citakan oleh undang-undang. Dimana seringkali terjadi dalam pelaksanaan pengadaan tanah untuk kepentingan umum tidak memperhatikan kemaslahatan pemegang hak perorangan, dalam arti bahwa pemegang hak perorangan seringkali berada dalam posisi yang dirugikan oleh pemerintah.
\end{abstract}

Kata Kunci :pengadaan tanah, ganti kerugian, pertanggungjawaban.

\section{Pendahuluan}

Pengadaan tanah untuk

kepentingan umum merupakan realisasi dari amanat pasal 6, 27, 34, 40 UUPA, dan kedua sebagai amanat dari Undang-undang no 39 Tahun 
1999 tentang Hak Asasi Manusia yang mengamanatkan bahwa sebagai konsekuensi sumberdaya tanah merupakan salah satu bagian dari HAM (Koeswahyono,2012:100) dan dasar-dasar hukum dari pengadaan hak atas tanah ini yang pertama berdasarkan Pasal 18 UndangUndang No. 5 Tahun 1960 tentang Peraturan Dasar Pokok-pokok Agraria yang menyatakan bahwa untuk kepentingan umum, termasuk kepentingan Negara serta kepentingan bersama dari rakyat, hak-hak atas tanah dapat dicabut, dengan memberi ganti kerugian yang layak dan menurut cara yang diatur dengan Undang-undang (Koeswahyono, 2012:101).

Masalah pokok yang menjadi sorotan atau perhatian dalam pelaksanaan pengadaan hak atas tanah adalah :"Menyangkut hak-hak atas tanah yang status dari hak atas tanah itu akan dicabut atau dibebaskan, sehingga dapat dikatakan bahwa unsur yang paling pokok dalam pengadaan hak atas tanah adalah ganti rugi yang diberikan sebagai pengganti atas hak yang telah dicabut atau dibebaskan" Abdurrahman, 1983:23).
Berdasarkan pasal 1 ayat

Undang-undang Republik Indonesia Nomor 2 Tahun 2012 Tentang Pengadaan Tanah Bagi Pembangunan Untuk Kepentingan Umum bahwa yang dimaksud dengan pengadaan tanah untuk pentingan umum adalah kegiatan menyediakan tanah dengan cara memberi ganti kerugian yang layak dan adil kepada pihak yang berhak (Pasal 1 ayat (2) Undang-undang Republik Indonesia Nomor 2 Tahun 2012). Kemudian ditegaskan kembali pada Pasal 3 Undang-undang Republik Indonesia Nomor 2 Tahun 2012 yaitu :"Pengadaan Tanah untuk Kepentingan Umum bertujuan menyediakan tanah bagi pelaksanaan pembangunan guna meningkatkan kesejahteraan dan kemakmuran bangsa, negara, dan masyarakat dengan tetap menjamin kepentingan hukum Pihak yang Berhak”.

Dalam praktek pengadaan tanah yang dilakukan oleh pemerintah seringkali tidak sesuai dengan citacita undang-undang. Dimana seringkali terjadi dalam pelaksanaan pengadaan tanah untuk kepentingan umum tidak memperhatikan kemaslahatan pemegang hak 
perorangan, pemegang hak perorangan seringkali berada dalam posisi yang dirugikan oleh pemerintah.

Pengadaan tanah untuk kepentingan umum di desa jala merupakan salah satu contoh kesewenang-wenangan pemerintah dalam menguasai hak atas tanah. Dalam kasus ini pemerintah daerah Dompu pada tahun 2012 melaksanakan program pengadaan tanah untuk kepentingan umum, dimana pemerintah menyediakan lahan atau tanah untuk keperluan pemukiman warga. Tanah yang digunakan atau yang disediakan oleh pemerintah daerah untuk pemukiman tersebut adalah tanah hak milik beberapa warga desa Jala. Dalam proyek pemukiman tersebut warga desa jala yang berpenghasilan rendah dipersilahkan oleh pemerintah untuk membangun rumah diatas tanah yang sudah disediakan. Selain aktivitas pembangunan rumah, dapat dijumpai juga pembangunan sarana dan prasaran oleh pemerintah yaitu pembangunan puskesmas, kantor desa maupun jalan raya yang bertujuan untuk memudahkan masyarakat desa jala.
Pada pelaksaan proyek tersebut pemerintah daerah Dompu tidak mengindahkan prosedur yang dimanatkan oleh Undang-Undang Nomor 2 Tahun 2012 Tentang Pengadaan Tanah Bagi Kepentingan Umum, dimana undang-undang ini menginginkan penyelenggaraan pengadaan tanah untuk kepentingan umum, memperhatikan keseimbangan antara kepentingan pembangunan dan kepentingan masyarakat yang hak atas tanahnya digunakan. Sedangkan pelaksanaan pengadaan tanah di desa Jala ditemui banyak kekurangan dan penyimpangan dimana pemerintah tidak melibatkan masyarakat sebagai pemilik hak atas tanah dalam beberapa hal, pertama pemerintah tidak membicarakan atau mensosialisasikan terlebih dahulu proyek tersebut kepada masyarakat, kemudian yang kedua, pemerintah memutuskan secara sepihak dalam menentukan besar ganti rugi atas tanah yang digunakan dalam proyek pemukiman warga desa Jala, dan yang paling fatal adalah penetapan besaran ganti rugi dilakukan setelah bertahun-tahun dilaksanakannya 
proyek pemukiman warga desa Jala tersebut.

Penyimpangan-penyimpangan dalam pelaksanaan pengadaan tanah oleh pemerintah daerah kabupaten Dompu tidak sebatas itu saja, namun masih ada penyimpangan lain yaitu pelaksanaan ganti rugi yang tidak beres yang mengakibatkan kerugian yang sangat besar bagi pemegang hak atas tanah yang digunakan dalam proyek pengadaan tanah pemukiman warga desa Jala tersebut. Yang dimaksud oleh penulis tidak beres adalah pemerintah mulai dari tahun 2012 sampai dengan tahun 2017 belum memberikan pelunasan ganti rugi kepada pihak-pihak atau masyarakat pemegang hak atas tanah, hal ini menunjukan tidak adanya rasa tanggung jawab pemerintah daerah Dompu untuk menyelesaikan permasalahan ganti rugi tersebut dengan tuntas dan tidak merugikan pihak manapun.

Berbicara mengenai ganti rugi maka dalam Pasal 9 ayat (2) Undangundang nomor 2 tahun 2012 tentang Pengadaan Tanah Bagi Pembangunan Untuk Kepentingan Umum, menyatakan bahwa, pengadaan tanah untuk kepentingan umum dilaksanakan dengan pemberian ganti kerugian yang layak dan adil (Pasal 9 Undag-undang Republik Indonesia Nomor 2 Tahun 2012). Pemberian ganti rugi yang layak dan adil sesuai dengan aturan dan tata cara yang diatur oleh undang-undang dari penentuan besar ganti rugi yang dilakukan secara musyawarah dan pemberian ganti rugi yang sesuai batas waktu yang diberikan oleh undang-undang.

Aturan berbicara demikian namun pada kenyataan atau imlementasinya ganti rugi dan keadilan tidak didapatkan oleh masyarakat desa jala. Masyarakat dalam hal ini mengalami krisis keadilan, sebagaimana yang dikatakan oleh Rahmad Safa'at (2011:14) bahwa krisis merupakan keadaan tidak normal oleh karena berbagai institusi yang disiapkan untuk menata berbagai proses dalam masyarakat tidak mampu menjalankan fungsinya dengan baik. Pemerintah daerah kabupaten Dompu misalnya yang seharusnya menaungi dan mengatur masyarakat agar tercipta daerah dan masyarakat yang sejahtera namun kenyataanya tugas dan fungsinya sebagai 
pemerintah lebih dipakai dan didominasi oleh kepentingan dan kekuasaan semata.Implikasi dari adanya penyimpanganpenyimpangan oleh pemerintah kabupaten Dompu dalam pengadaan tanah pemukiman tersebut adalah terjadinya kemiskinan,.

Berdasarkan latar belakang masalahyang telah diuraikan tersebut di atas, maka dapat ditarik beberapa rumusan masalah 1) Mengapa terjadi penyimpangan pelaksanaan ganti rugi oleh Pemerintah Daerah Dompu dalam pelaksanaan proyek pengadaan tanah pemukiman warga desa Jala? 2) Bagaimanakah bentuk tanggung jawab Perdata Pemerintah Daerah Dompu bila dalam pelaksanaan proyek pengadaan tanah pemukiman warga desa Jala terdapat penyimpangan? 3) Bagaimanakah seharusnya pelaksanaan ganti rugi dan tanggung jawab Pemerintah Daerah Dompu dalam proyek pengadaan tanah pemukiman warga desa Jala?

\section{Tujuan Penelitian}

Untuk mengetahui, memahami dan menganalisis mengapa terjadi penyimpangan pelaksanaan ganti rugi oleh Pemerintah Daerah Dompu dan bentuk tanggung jawab Perdata Pemerintah Daerah Dompu

\section{Metode Penelitian}

Penelitian ini merupakan penelitian hukum (Legal Research), yang merupakan serangkaian tindakan atau proses untuk menemukan hukum disebabkan terjadinya kekosongan hukum (vacuum norm), kekaburan norm (obscuur norm) maupun konflik norm (conflict of norm) atau menemukan asas hukum, yang mengatur norma hukum yang mengikat secara umum dan dibentuk atau ditetapkan oleh lembaga atau pejabat yang berwenang melalui prosedur yang ditetapkan dalam peraturan perundang-undangan,

\section{Hasil dan Pembahasan}

PenyebabPenyimpangan

Pelaksanaan Ganti Rugi Oleh Pemerintah Daerah Dompu Dalam Pengadaan Tanah

Penyebab atau alasan mengapa penyimpangan pelaksanaan ganti rugi terjadi karena tidak terjalinnya komunikasi atau musyawarah antara masyarakat dan pemerintah untuk saling mengikatkan dirinya pada sebuah perjanjian yang seharusnya sama-sama disepakati. Hasil 
Wawancara dengan Bapak H.Yunus, Tasrin, Nurmi dan Armi sebagai pihak yang berhak/ pihak yang memegang hak atas tanah (23 Maret 2017) diperoleh data bahwa dalam penyelenggaraan pengadaan tanah pemukiman warga desa Jala, pemerintah menggunakan tanah masyarakat tanpa membicarakan atau meminta persetujuan masyarakat terlebih dahulu. Tanah-tanah tersebut langsung digunakan oleh pemerintah dan setelah digunakan barulah pemerintah membangun komunikasi dengan masyarakat dengan mengumumkan secara langsung dan diwakili oleh Kepala Desa bahwa harga tanah yang ditawarkan oleh pemerintah adalah $1.500 .000 / 100$ M2.

Sesungguhnya tanpa adanya proses musyawarah antara pemegang hak atas tanah dan pihak/instansi pemerintah yang memerlukan tanah, pengadaan tanah bagi pelaksanaan pembangunan untuk kepentingan umum tidak akan pernah terjadi atau terealisasi dalam implementasinya sebab musyawarah dalam kontek pengadaan tanah untuk kepentingan umum harus dipahami dan dikaitkan dengan kesepakatan sebagai salah satu syarat sahnya perjanjian sebagai mana tertuang dalam pasal 1320 Kitab UndangUndang Hukum Perdata atau yang disingkat dengan (KUHPerdata). Menurut pasal 1320 KUHPerdata untuk sahnya perjanjian diperlukan empat syarat (Simanjuntak, 2014:287) yaitu :

1) sepakat mereka yang mengikatkan dirinya;

2) cakap untuk membuat suatu perikatan;

3) suatu hal tertentu; dan

4) suatu sebab yang halal.

Kata sepakat sebagai salah satu syarat sahnya perjanjian mengandung arti bahwa kedua belah pihak harus mempunyai kebebasan kehendak. Para pihak tidak mendapat tekanan apapun yang mengakibatkan adanya "cacat" bagi perwujudan kehendak bebas tersebut (Hijratul, 2014:19). Berkenaan dengan hal ini panitia pengadaan tanah dan masyarakat desa Jala harus memiliki kedudukan yang sama dan tidak diperbolehkan ada pihak yang di paksakan atau berada dibawah kendali pihak yang memiliki kekuasaan dalam mengambil keputusan dan atau menyampaikan kesepakatan. Namun yang terjadi 
justru sebaliknya. Dimana berdasarkan posisi kasus yang sudah penulis jelaskan diatas bahwa panitia pengadaan tanah atau pemerintah menggunakan tanah tanpa sepengetahuan masyarakat dan penentuan besar ganti kerugian pun diputuskan secara sepihak yang artinya masyarakat tidak diberikan hak bebas untuk berkehendak.

Berdasarkan hasil wawancara dengan Mustamin, Nurmi, Tasrin, H.M Yunus dan Firman Pemegang hak atas tanah (27 Maret 2017), reaksi masyarakat terhadap penentuan ganti rugi yang tidak layak dan dilakukan secara sepihak oleh panitia pengadaan tanah adalah menolak dengan tegas untuk diberikan ganti rugi sebesar Rp $1.500 .000,-/ 100 \quad \mathrm{M} 2$, masyarakat menginginkan ganti kerugian yang layak dan sesuai dengan harga pasar, sehingga uang yang diperoleh dari ganti kerugian tersebut dapat digunakan kembali untuk membeli tanah. Ketika harus menerima ganti kerugian dengan nominal yang telah ditentukan oleh pemerintah maka, masyarakat tidak dapat membeli tanah kembali, dan hal tersebut sangat merugikan masyarakat.
Jika peristiwa diatas dianalisis maka dalam proyek tersebut dapat dikatakan belum terjadi perikatan perjanjianantara para pihak. Karena dalam pelaksanaannya tidak dillakukan musyawarah dan secara otomatis tidak akan terjadi kesepakatan. Ini berarti unsur esensial dari perjanjian yaitu sepakat tidak dipenuhi. Sebagaimana yang dinyatakan oleh Muhammad Bakri bahwa perikatan timbul karena perjanjian atau undang-undang. Unsur esensial dari perjanjian adalah kata sepakat diantara para pihak yang membuat perjanjian itu sehingga tiada perjanjian tanpa kata sepakat (Bakri, 2011:170). Oleh karena itu harus dibangun musyawarah terlebih dahulu antara masyarakat dan pemerintah sebagai wadah untuk memperoleh kesepakatan.

Pasal 1233 KUH Perdata yang menyatakan bahwa tiap-tiap perikatan dilahirkan baik karena persetujuan, baik karena undangundang. Jadi berdasarkan hal ini dapat ditekankan kembali bahwa masyarakat tidak pernah menyetujui besaran ganti rugi yang ditentukan oleh panitia pengadaan tanah. oleh karena itu tidak ada perjanjian yang 


mengikat antara masyarakat
pemegang hakatas tanah dengan
panitia pengadaan tanah atau
pemerintah daerah Kabupaten
Dompu.

\section{Dalam penyelenggaraan} pengadaan tanah pemukiman warga desa Jala sebagaimana yang sudah penulis konstruksikan sebelumnya bahwa tidak ada sosialisasi dan musyawarah oleh pemerintah. Sehingga pemerintah secara langsung tanpa sepengetahuan pemegang hak atas tanah langsung menggunakan tanah. setelah digunakan barulah pemerintah memberitahukan maksud penggunaan tanah tersebut sekaligus menetukan harga secara sepihak. Karena tanahnya sudah digunakanoleh pemerintah maka secara terpaksa masyarakat menyetujui atau menyepakati tanah mereka untuk digunakan. Padahal pada posisinya masyarakat tidak ingin mengalihkan barang sejengkalpun tanah milik mereka kepada pihak manapun (hasil wawancara dengan Firman, Nurmi, Tasrin dan Darwis sebagai pihak yang berhak atas ganti kerugian, 5 April 2017). Dalam hal ini tidak ada kesepakatan terkait dengan objek yang digunakan oleh panitia pengadaan tanah. masyarakat menyatakan sepakat karena takut dengan kekuasaan yang dimiliki oleh pemerintah. Sehingga dalam hal ini masyarakat tidak berada pada posisi yang seharusnya, justru berada pada posisi yang ditekan oleh pihak pemerintah. Sehubungan dengan syarat kesepakatan, dalam KUHPerdata dicantumkan beberapa hal yang dapat menyebabkan cacatnya suatu kesepakatan, yaitu kekhilafan, paksaan, atau penipuan. Hal ini ditegaskan dalam pasal 1321 KUHPerdata yang berbunyi, "Tiada kata sepakat yang sah apabila sepakat itu diberikan karena kekhilafan, atau diperolehnya dengan paksaan atau penipuan".

Berdasarkan pada pasal 1321 KUHPerdata tersebut menandakan bahwa persetujuan masyarakat untuk menyerahkan tanah kepada pemerintah merupakan kesepakatan yang tidak sah karena masyarakat dalam memberikan persetujuan berada dalam ketakutan dan penekanan dari pemerintah

Mengenai bentuk tanggung Jawab perdata Pemerintah Daerah 
Dompu dalam penyimpangan pelaksanaan proyek pengadaan tanah pemukiman warga Desa Jala, menurut Roscoe Pound jenis tanggung jawab ada tiga yaitu pertanggungjawaban atas kerugian dengan disengaja, atas kerugian karena kealpaan dan tidak disengaja, dalam perkara tertentu atas kerugian yang dilakukan tidak karena kelalaian serta tidak disengaja Bakri, 2011:170). Menurut Roscoe Pound tanggung jawab bersumber dari (Bakri, 2011:170):

a) Perjanjian, dimana para pihak mengadakan perjanjian tersebut masing-masing di tuntut untuk bertanggungjawab atas pemenuhan isi perjanjian yang mereka buat.

b) Perbuatan melawan hukum yang terbagi atas :

1) Perbuatan diri sendiri, baik yang disengaja (dolus) maupun yang tidak disengaja (culpa)

2) Perbuatan orang lain ( orang yang masih berada dibawah tanggungan si penanggung jawab yang bersangkutan)

3) Kejadian lain yang bukan merupakan perbuatan, tetapi menimbulkan akibat yang tetap harus dipertanggungjawabkan oleh orang, yang oleh hukum dianggap sebagai penanggungjawabnya.

Dari kedua sumber tanggung jawab yang di nyatakan oleh Roscoe
Pound tersebut maka, sumber yang termasuk dalam kasus pengadaan tanah proyek pemukiman warga desa Jala ialah perbuatan melawan hukum. Dalam kasus ini Pemerintah dikatakan telah melakukan perbuatan melawan hukum karena dalam pelaksanaannya telah menyimpangi perintah Undang-undang No 2 Tahun 2012 Tentang Pengadaan Tanah Bagi Pembangunan Untuk Kepentingan Umum dan Peraturan perundangundangan yang terkait lainnya.

Suatu perbuatan melawan hukum harus mempunyai beberapa unsur sebagaimana berikut:

a) Adanya suatu perbuatan melawan hukum,

b) Adanya suatu unsur kesalahan,

c) Adanya suatu kerugian yang diderita,

d) Adanya suatu hubungan kausalitas antara kesalan dan kerugian.

Dari unsur-unsur tersebut harus dapat terpenuhi, ketika seseorang akan meminta pertanggungjawaban perdata dari seseorang (Bakri, 2011:304).

Penyimpangan yang dilakukan oleh Pemerintah Daerah Dompu dalam pelaksanaan pengadaan tanah 
untuk keperluan proyek pemukiman warga desa Jala telah memenuhi unsur-unsur perbuatan melawan hukum sebagaimana yang telah diuraikan diatas. Sehingga dalam hal ini Pemerintah daerah Dompu memiliki kewajiban untuk memberikan pertanggungjawaban kepada masyarakat dengan bentuk memberikan ganti kerugian.

Apabila penyimpangan yang dilakukan oleh Pemerintah Daerah Dompu diuraikan menurut unsurunsur perbuatan melawan hukum menurut pasal 1365 KUH Perdata adalah sebagai berikut :

\section{a) Adanya Perbuatan Melawan Hukum.}

Pengadaan tanah yang diselenggarakan oleh Pemerintah Daerah Dompu terdapat banyak penyimpangan mulai dari tidak dilaksanakannya musyawarah sampai dengan tidak diberikannya ganti kerugian kepada sebagian besar masyarakat pemegang hak atas tanah, hal ini merupakan perbuatan melawan hukum karena telah berlawanan dengan kewajiban hukum yang berlaku maupun hakhak pemegang hak atas tanah itu sendiri.
Tentang kerugian yang diderita masyarakat Desa Jala akibat dari perbuatan melawan hukum oleh Pemerintah Daerah Dompu, dimana kerugian yang ditimbulkan ialah tidak diterimanya uang ganti kerugian atas tanah yang telah digunakan, kerugian atas tanaman yang melekat diatas tanah, kerugian atas penghasilan yang seharusnya, kerugian atas biaya yang dikeluarkan untuk mengurus segala keperluan dalam mengupayakan ganti kerugian, dan kerugian atas kecemasan dan kekhawatiran masyarakat. Yang kesemuanya dinamakan kerugian materiel maupun kerugian immaterial.

\section{b) Adanya kesalahan}

Kesalahan pemerintah dalam permasalahan ini ialah karena secara sengaja melakukan perbuatan yang melawan hukum dengan menyimpangi ketentuan-ketentuan yang diharuskan oleh Undangundang.

\section{c) Adanya hubungan kausal}

Dalam permasalahan ini jelas terdapat hubungan sebab akibat dimana akibat kesalahan yang dilakukan oleh Pemerintah daerah Dompu menyebabkan kerugian bagi 
pihak yang berhak (pemegang hak atas tanah). sehingga dengan demikian dapat dikatan bahwa perbuatan melawan hukum oleh Pemerintah Daerah Dompu adalah sebab, sedangkan kerugian yang dialami oleh Masyarakat pemegang hak atas tanah ialah akibatnya.

Dari uraian diatas dapat disimpulkan, bahwa akibat dari suatu perbuatan melawan hukum adalah timbulnya kerugian. Kerugian sebagai akibat perbuatan melawan hukum diharuskan supaya diganti oleh orang yang karena salahnya menimbulkan kerugian itu atau oleh si pelaku perbuatan melawan hukum. Dengan demikian, pasal 1365 KUHPer mengatur tentang kewajiban bagi si pelaku perbuatan melawan hukum untuk menggati kerugian yang timbul karenanya disatu pihak dan hak untuk menuntut penggantian kerugian bagi orang yang dirugikan. Berangkat dari analisis diatas maka Pemerintah Daerah Dompu diwajibkan untuk bertanggungjawab atas penyimpangan pelaksanaan ganti kerugian yang telah terjadi dalam proyek pengadaan tanah pemukiman warga desa Jala. dan oleh karena demikian maka sebagai bentuk tanggung jawabnya Pemerintah harus melakukan hal-hal sebagai berikut :

\section{a) Melakukan Musyawarah Penetapan Ganti Kerugian}

Pemerintah dalam rangka untuk menyelesaikan perselisihan ganti kerugian dengan masyarakat harus membangun komunikasi dengan menyelenggarakan musyawarah dengan maksud untuk melakukan pemecahan permasalahan secara bersama-sama. sekaligus mendata kembali siapa saja masyarakat yang tanahnya digunakan dalam proyek pemukiman, kemudian melakukan pengukuran atas luas tanah yang dugunakan. Hal ini bertujuan untuk memberikan kejelasan berapa banyak masyarakat yang telah menyerahkan tanahnya dalam proyek tersebut.

Maksud lain dari musyawarah ialah agar dapat menetapkan besaran ganti kerugian yang layak menurut kehendak dan keinginan para pihak yang ditandai dengan kata sepakat oleh keduanya. Pada prinsipnya Musyawarah ialah untuk mencapai mufakat yang merupakan pengamalan dari sila keempat Pancasila untuk mewujudkan demokrasi dalam kehidupan 
berbangsa, bernegara dan bermasyarakat.

Pada prinsipnya proses musyawarah sama dengan proses negosiasi dalam suatu perjanjian di mana para pihak berusaha mempertemukan keinginan masingmasing untuk mencapai win-win solution. Sebagaimana yang dikatakan oleh Rachhmad Safa'at (2011:85) bahwa negosiasi memberikan peluang yang sangat luas bagi para pihak untuk menentukan pilihan-pilihannya dan dalam negosiasi tidak ada yang kalah mutlak atau menang mutlak, semua pihak memperoleh kesempatan untuk menjelaskan berbagai persoalan dalam proses negosiasi. Berangkat dari uraian diatas maka sudah seharusnya Pemerintah daerah Kabupaten Dompu membangun musyawarah atau komunikasi dengan masyarakat guna menyelesaikan permasalahan-permasalahan yang ada..

\section{b) Memberikan Ganti Kerugian Atas Segala Kerugian Yang Dialami Oleh Pemegang Hak Atas Tanah.}

Pemerintah Daerah Dompu atas dasar perbuatannya yang melawan Hukum dan menimbulkan kerugian bagi masyarakat desa Jala yang hakhak atas tanahnya digunakan dalam proyek pengadaan tanah tersebut maka berdasarkan teori pertanggungjawaban dari Roscou Pound berkewajiban untuk memberikan ganti kerugian sebagai bentuk Tanggungjawab karena telah merugikan dan meresahkan masyarakat.

Ganti kerugian dalam hal ini penulis sebut sebagai bentuk pertanggungjawaban oleh pemerintah daerah Dompu atas perbuatannya yang telah merugikan masyarakat. Yang perlu diketahui bahwa harga tanah yang tidak diberikan oleh Pemerintah dari tahun 2012 hingga dengan tahun 2017 merupakan hak mutlak yang harus diterima oleh masyarakat karena tidak ada kewenangan pada negara untuk mengambil tanah tanpa adanya suatu ganti rugi. Indonesia bukan negara yang berideologi komunis yang memungkinkan penyitaan tanah tanpa ganti rugi.

Pada dasarnya Konsep ganti rugi di dalam hukum perdata berbeda dengan konsep ganti rugi dalam peraturan pengadaan tanah. Ganti rugi dalam hukum perdata timbul 
manakala terjadi wanprestasi atau perbuatan melawan hukum. Ganti rugi dalam hukum perdata terdiri dari 3 macam, yaitu biaya, kerugian dan bunga.

$\begin{array}{ccc}\text { R.Subekti } & \text { mendefinisikan } & \text { tiga } \\ \text { macam } & \text { ganti } & \text { rugi }\end{array}$ (schadevorgoeding) sebagai berikut :

1) Biaya (costen) Biaya adalah segala pengeluaran yang nyatanyata sudah dikeluarkan oleh satu pihak.

2) Kerugian (schaden) Kerugian adalah kerugian kerusakan barang-barang kepunyaan satu pihak yang diakibatkan oleh kelalaian pihak lawan atau wanprestasi.

3) Bunga (interesten) Bunga adalah keuntungan bunga yang hilang yang mempunyai kemiripan dengan verlies yang diartikan sebagai kerugian yang berupa kehilangan keuntungan yang sudah dihitung oleh kreditur.

Ganti rugi yang harus diberikan oleh Pemerintah Daerah Dompu ialah ganti kerugian mutlak yang sebagaimana telah diatur oleh Undang-undang No.2 Tahun 2012 Tentang Pengadaan Tanah Bagi Pembangunan Untuk Kepentingan
Umum dang anti rugi secara perdata karena telah melakukan perbuatan melawan hukum.

\section{TanggungjawabPemerintah} Daerah Dompu Dalam Proyek Pengadaan Tanah Pemukiman Warga Desa Jala

Pemberian ganti kerugian seharusnya mengedepankan prinsip keadilan. Dimana berdasarkan pendapat dari Aristoteles bahwa kata adil mengandung lebih dari satu arti .adil dapat berarti menurut hukum, dan apa yang sebanding, yaitu yang semestinya (Muliawan,2016:14). Dalam hal ini ditunjukan bahwa Pemerintah Daerah Dompu dalam melaksanakan proyek pengadaan tanah pemukiman warga desa Jala harus mengikuti mekanismemekanisme yang telah diatur oleh Undang-undang guna membawa kemasalahatan atau menciptakan pengadaaan tanah yang adil.

Berdasarkan pandangan dari Aristoteles diatas menunjukan bahwa Pemerintah daerah Dompu tidak berlaku adil dalam melaksanakan tugas dan fungsinya. Mengutip pandangan Djarot Widya Muliawan yang menyatakan bahwa apabila orang dalam melaksanakan tugasnya tidak menghiraukan hukum maka 
dapat dinyatakan tidak adil. (Muliawan,2016:14). Oleh karena itu, maka semakin jelas bahwa penyimpangan yang dilakukan oleh Pemerintah ialah perbuatan yang melanggar hukum dan tidak mencerminkan rasa keadilan.

Untuk dapat mencerminkan keadilan maka pelaksanaannya harus mengikuti mekanisme yang seharusnya yakni dengan berpedoman pada ketentuanketentuan yang diatur dan diamanatkan dalam Undang-undang yang berlaku dan terkait. Sebab dalam mekanisme tersebut terdapat runtutan yang harus dilaksanakan yaitu :

1) penilaian ganti kerugian;

2) musyawarah ; dan

3) pemberian ganti kerugian.

3 (tiga) komponen ini merupakan mekanisme yang seharusnya atau pelaksanaan dan pertanggungjawaban yang seharusnya yang tidak dapat diliwatkan dalam proses pelaksanaan ganti kerugian sebab tahapan tersebutlah yang sangat penting dalam proses pelaksanaan pemeberian ganti kerugian dan ketiga proses ini pula akan menimbulkan hubungan keperdataan bagi para pihak yang akan menciptakan perjanjian besaran nilai ganti kerugian yang didasarkan kesepakatan yang adil.

$$
\text { Jika mempertanyakan }
$$
pelaksanaan ganti rugi dan tanggung jawab yang seharusnya, maka jawababnya ialah dengan mengikuti dan melaksanakan proses-proses diatas. Ketiga Tahapan dalam proses pelaksanaan ganti kerugian yang telah penulis uraikan diatas merupakan perintah undang-undang yang harus dilaksanakan. Jika dicermati ketiga proses tersebut sangatlah penting untuk dilaksanakan karena dalam proses itulah komunikasi masyarakat dan pemerintah dibangun. sehingga akan tercapailah persesuaian keinginan antara pemegang ha katas tanah dan pemerintah yang mengedepankan keadilan.

Dalam bagian menimbang Undang-undang Nomor 2 Tahun 2012 Tentang Pengadaan Tanah Bagi Pembangunan Untuk Kepentingan Umum dinyatakan bahwasannya pengadaan tanah harus dilakukan dengan mengedepankan prinsip kemanusiaan, demokratis dan adil. 
Idealnya pemerintah harus itu sendiri merupakan keutamaan melaksanakannya sesuai dengan moral (Muliawan,2016:14) dalam aturan yang ada. Namun pada implementasinya sangat jauh dari harapan Undang-undang (Bagian menimbang Undang-undang Nomor 2 Tahun 2012).

Berdasarkan hasil penelitian penulis bahwa Pemerintah dalam iplementasinya tidak melaksanakan proses-proses yang telah diuraikan diatas. Oleh karena itu, mengutip pandangan dari Aristoteles bahwa orang yang tidak menghiraukan hukum juga dapat dikatakan sebagai perbuatan yang tidak adil, sehingga dalam hal ini pemerintah tidak berlaku adilkepada masyarakat. Pemerintah seakan menutup mata dengan kerugian dan keterpurukan yang dialami oleh masyarakat.

Aristoteles mengemukakan bahwa keadilan merupakan suatu kebijakan politik yang aturanaurannya menjadi dasar dari peraturan negara dan aturan-aturan ini merupakan ukuran apa yang hak dan apa yang bukan hak. Lebih lanjut dikatakan bahwa agar terdapat suatu keadilan maka orang harus memperoleh keuntungan dengan cara-cara yang wajar, dan keadilan hal ini ditekankan bahwa adanya keutamaan moral. Dalam peneyelenggaraan Pemerintah sama sekali tidak mengedepankan moral. Pemerintah hanya memperhatikan keberhasilan bangunan yang tengah dibangun pada saat itu.

Ditinjau dari isinya Aristoteles membedakan adanya dua maca keadilan yaitu Justitia distributive (Keadilan Distributif) dan Justitia Commutativa (keadilan komutatif). Keadilan distributive artinya keadilan yang diberikan didasarkan pada kedudukan atau peran subjek hukum tersebut. Jadi keadilan untuk satu orang pemegang hak atas tanah berbeda dengan pemegang hak atas tanah lainnya. Dan sudah tentu bahwa dalam meberikan ganti kerugian maka nilai ganti kerugian yang diterima setiap orang berbeda berdasakan pada luas dan besar tanah yang digunakan oleh pemerintah hal ini bertati tergantung pada kontribusinya masing-masing.

Sedangkan keadilan komulatif merupakan keadilan yang diberikan untuk satu orang sama dengan orang lain. Jadi keadilan untuk satu orang 
pemegang hak atas tanah sama dengan pemegang hak atas tanah lainnya. Dalam hal ini dapat diartikan bahwa keasamaan harga dasar tanah yang diterapkan pada semua pemegang hak atas tanah. dan juga dapat diartikan bahwa dalam pengadaan tanah lainnya pemgenag hak atas tanah diberikan ganti kerugian oleh pemerintah sedangkan pada pelaksanaan pengdaan tanah pemukiman warga desa Jala tidak diberikan. Idealnya masyarakat harus sama-sama memperoleh ganti kerugian tersebut.

Keadilan dalam memberi ganti kerugian diterjemahkan sebagai mewujudkan penghormatan kepada seorang yang haknya dikurangi dengan memberikan imbalan berupa sesuatu yang setara dengan keadaannya sebelum hak tersebut dikurangi atau diambil, sehingga yang bersangkutan tidak mengalami degradasi kesejahteraan Sumardjono,2007:180).

Berdasarkan hasil wawancara dengan Bapak Armi sebagai pihak yang berhak atau pemegang hak atas tanah (21 Maret 2017) bahwa pada pelaksanaan Proyek Pengadaan tanah pemukiman warga desa Jala ini,
Pemerintah Kabupaten Dompu memberikan kesan bahwa Pemerintah tidak berupaya agar rasa keadilan bagi pemilik/pemegang Hak Atas Tanah dapat terpenuhi. Tidak adanya upaya Keadilan yang dimaksudkan adalah Pemerintah dalam melaksanakan proyek tidak mengindahkan perintah-perintah Undang-undang yang mengedepankan prinsip kesejahteraan dan keadilan bagi rakyat.

\section{Simpulan}

Berdasarkan hasil penelitian dan analisis yang penulis sajikan pada bab-bab terdahulu, berikut disajikan kesimpulan yang merupakan jawaban terhadap permasalahan dalam penelitian ini sebagai berikut :

1) Penyebab terjadinya penyimpangan pelaksanaan Ganti Rugi oleh Pemerintah Daerah Dompu dalam Pelaksanaan Proyek Pengadaan Tanah Pemukiman Warga Desa Jala.

Penyebab terjadinya penyimpangan Pelaksanaan Ganti Kerugian dalam Proyek Pengadaan Tanah Pemukiman Warga Desa Jala ialah karena tidak dilaksanakannya 
sosialisasi dan musyawarah oleh Pemerintah Daerah Dompu yang merupakan wadah untuk mempertemukan kehendak antara Pemerintah dan Masyarakat yang berkenaan dengan penggunaan objek hak atas tanah dan besaran biaya ganti kerugian dalam Proyek Pemukiman Warga Desa Jala. Oleh karena itu menunjukan bahwa tidak adanya kesepakatan harga antara kedua belah pihak dan oleh karena perbuatannya yang menimpang dari ketentuan Undang-undang maka Pemerintah dapat dikatakan telah melakukan perbuatan melawan hukum yang menimbulkan kerugian maateriel maupun Immateriel yang dapat dimintai pertanggungjawaban perdata oleh pihak-pihak yang dirugikan.

2) Bentuk Tanggung Jawab Perdata Pemerintah Daerah Dompu bila dalam Pelaksanaan Proyek Pengadaan Tanah Pemukiman Warga Desa Jala Terdapat Penyimpangan?

a) Melakukan Musyawarah Penetapan Ganti Kerugian

b) Memberikan Ganti Kerugian Atas Segala Kerugian Yang
Dialami Oleh Pemegang Hak Atas Tanah

3) Pelaksanaan Ganti Kerugian dan Tanggung Jawab yang seharusnya oleh Pemerintah Daerah Dompu dalam Proyek Pengadaan Tanah Pemukiman warga Desa Jala.

Idealnya pelaksanaan ganti kerugian harus dilaksanakan berdasarkan ketentuan Undangundang Nomor 2 Tahun 2012 Tentang Pengadaan Tanah Bagi Pembangunan Untuk Kepentingan Umum. Sebab dalam Undangundang tersebut sangat mengedepankan prinsip kemanusiaan, demokrasi dan Keadilan.Dalam Undang-undang Nomor 2 Tahun 2012 Tentang Pengadaan Tanah Bagi Pembangunan Untuk Kepentingan Umum mengharuskan untuk dilaksanakannya Penilaian ganti kerugian, kemudian musyawarah penetapan ganti kerugian agar tercapai kesepakatan nilai ganti kerugian dan pemberian ganti kerugian yang sesuai dengan hasil kesepakatan kepada pihak yang berhak. Keharusan tersebut wajib dilaksanakan agar tercapai 
pelaksanaan ganti kerugian yang layak dan adil bagi masyarakat.

\section{Daftar Pustaka}

Abdurrahman, 1983, Masalah Pencabutan Hak Atas Tanah Dan Pembebasan Tanah Di Indonesia, Alumni, Bandung.

Amirudin dan Zainal Asikin,2004, Pengantar Metode Penelitian Hukum, Raja Gravindo Persada, Jakarta

A.P. Parlindungan, 1990, Pencabutan Hak Atas Tanah Menurut Sistem UUPA, Cetakan II, Mandar Maju, Bandung

Adrian Sutedi, 2008, Implementasi Prinsip Kepentingan Umum Dalam Pengadaan Tanah Untuk Pembangunan, Sinar Grafika, Jakarta

A. Qiram Syamsudin Meliala, Pokok-Pokok Hukum Perjanjian Beserta Perkembangannya, Liberty, Yogyakarta

A. A. Oka Mahendra, 1996, Menguak Masalah Hukum Demokrasi Dan Pertanahan, Cet.1. Pustaka Sinar Harapan,Jakarta

Ahmadi Miru, 2010, Hukum Kontrak Perancangan Kontrak, Rajawali, Jakarta

Boedi Harsono, 1991,Hukum Agraria Indonesia Himpunan PeraturanPeraturan Hukum Tanah,
Cetakan Kesepuluh, Penerbit Djambatan, Jakarta

Boedi Harsono, 2003, Hukum Agraria Indonesia Sejarah Pembentukan UUPA, Isi dan Pelaksanaannya, Penerbit Djambatan, Jakarta

Bernhard Limbong, 2011, Pengadaan Tanah Untuk Pembangunan Regulasi Kompensasi Penegakan Hukum, Margaretha Pustaka, Jakarta

Carl Joachim Friedrich, 2004, Filsafat Hukum Perspektif historis, Nuansa dan Nusa Media, Bandung

Darji Darmodiharjo, 2006, Pokokpokok Filsafat Hukum, Gramedia Pustaka Utama, Jakarta.

F.X. Adji Samekto, dkk, 2001, Hukum Birokrasi dan Kekuasaan di Indonesia , Walisongo research Institute, Semarang

Gunanegara, 2008, Rakyat dan Negara Dalam Pengadaan Tanah Untuk Pembangunan, Tata Nusa, Jakarta

H. Idham, 2004, Konsolidasi Tanah Perkotaan dalam Perspektif Otonomi Daerah, Alumni, Bandung

Jarot Widya Muliawan, 2016, Cara Mudah Pahami Pengadaan Tanah Utuk Pembangunan, Litera, Jogjakarta 
Rumah Tinggal, edisi revisi, Buku Litera, Yogyakarta.

Kahar Masyhur, 1985, Membina Moral dan Ahlak, Kalam Mulia, Jakarta

Maria S.W. Sumardjono, 2006, Tanah Dalam Perspektif Hak Ekonomi Sosial dan Budaya, Kompas, Jakarta

2001, Kebijakan Pertanahan Antara Regulasi Dan Implementasi, Cetakan I, Kompas Jakarta

Masyhur Efendi,1994, Dimensi dan dinamika Hak Asasi Manusia Dalam Hukum Nasional dan Internasional, Ghalia Indonesia, Jakarta

Munir Fuady, 2002, Perbuatan Melawan Hukum, Citra Aditya Bakti, Bandung.

Muhammad Bakri, 2011, Hak Menguasai Tanah Oleh Negara, UB Press, Malang

Phillipus M. Hadjon, 1987, Perlindungan Hukum Rakyat Indonesia, PT. Bina Ilmu, Surabaya

Parlindungan A.P, 1994, Bunga Rampai Hukum Agraria, Cetakan II, CV. Mandar Maju, Bandung

Rachmad Safa'at , 2011, Advokasi Dan Alternatif Penyelesaian Sengketa ( Latar belakang, Konsep dan Implementasinya), Surya Pena Gemilang, Malang.
Ridwan HR,2006, Hukum Administrasi Negara, Raja Grafindo Persada, Jakarta

R. Wirjono Prodjodikoro, 1989, Asas-asas Hukum Perjanjian, Sumur Bandung, Jakarta

Rianto Andi, 2004, Metodologi Penelitian Sosial dan Hukum, Granit, Jakarta

Ronny Hanitjio, 1988, Metodologi Hkum dan Juri Metri, Ghalia, Jakarta

Soimin,2001,Status Hak Dan Pembebasan Tanah, Cetakan II, Sinar Grafika

Satjipto Rahardjo, 2003, Sisi-sisi Lain dari Hukum di Indonesia, Kompas, Jakarta

Satjipto Rahardjo, 1989, Penyelenggaraan Keadilan Dalam Masyarakat Yang Sedang Berubah (Masalahmasalah Hukum ), Kompas, Jakarta

Shidarta, 2006, Hukum Prlindungan Konsumen Indonesia, Grasindo, Jakarta

P.N.H. Simanjuntak, 2014, Hukum Perdata Indonesia, Prenadamedia, Jakarta

Wartaya Winangun, 2004, Tanah Sumber Nilai Hidup, Kanisius, Yogyakarta

Roscoe Pound, 1996, Pengantar Filsafat Hukum (An Introduction to the Philosophy of law) diterjemahkan oleh Mohammad Radjab, 
Bharatara Niaga Media,

Jakarta.

\section{Undang-Undang}

Undang-undang Republik Indonesia

Nomor 2 Tahun 2012

Tentang Pengadaan Tanah

Bagi Pembangunan Untuk

Kepentingan Umum.

Peraturan Presiden Nomor 71 Tahun

2012

Tentang

Penyelenggaraan

Pengadaan Tanah Bagi

Pembangunan Untuk

Kepentingan Umum.

$\begin{array}{rrr}\text { Peraturan Presiden } & \text { Repblik } \\ \text { Indonesia Nomor } 148 \\ \text { Tentang } & \text { Perubahan } \\ \text { Keempat Atas } & \text { Peraturan } \\ \text { Presiden Nomor } & 71 \text { Tahun } \\ 2012 & \text { Tentang } \\ \text { Penyelenggaraan } & \\ \text { Pengadaan Tanah } & \text { Bagi } \\ \text { Pembangunan } & \text { Untuk } \\ \text { Kepentingan Umum }\end{array}$

\section{JURNAL}

Imam Koeswahyono, Mengkritisi Undang-undang Pengadaan Tanah No.2 Tahun 2012 dan implikasi sosialnya, dalam Jurnal Varia Peradilan No.319 Juni 2012. 